\title{
Bloedvaten en epilepsie
}

De ontdekking dat er een speciale barrière aanwezig is tussen de hersenen en het bloed werd in het begin van de twintigste eeuw gedaan door Ewald Franke (een student werkzaam in de groep van Nobelprijswinnaar Paul Ehrlich) en Edwin Ellen Goldmann. Goldmann verbaasde zich over het feit dat na een lumbale injectie met een tripaanblauwoplossing het ruggenmerg en de hersenstam blauw kleurden, terwijl de kleine en grote hersenen geen blauwkleuring vertoonden (figuur I).

Meer dan honderd jaar later weten we dat deze bevindingen verklaard kunnen worden door de aanwezigheid van de bloed-hersenbarrière, die uiterst belangrijk is voor het normaal functioneren van hersencellen. De afgelopen jaren is binnen het epilepsieveld veel onderzoek verricht naar de functie en dysfunctie van de bloed-hersenbarrière. In de volgende twee bijdragen wordt verder ingegaan op de effecten van schade aan bloedvaten op epilepsie. Hierbij besteden we aandacht aan lekkage van de bloedhersenbarrière bij temporaalkwabepilepsie, één van de meest voorkomende typen epilepsie bij volwassenen en aan hersenbloedingen, die net als temporaalkwabepilepsie veel voorkomen en een oorzaak kunnen zijn van epilepsie.

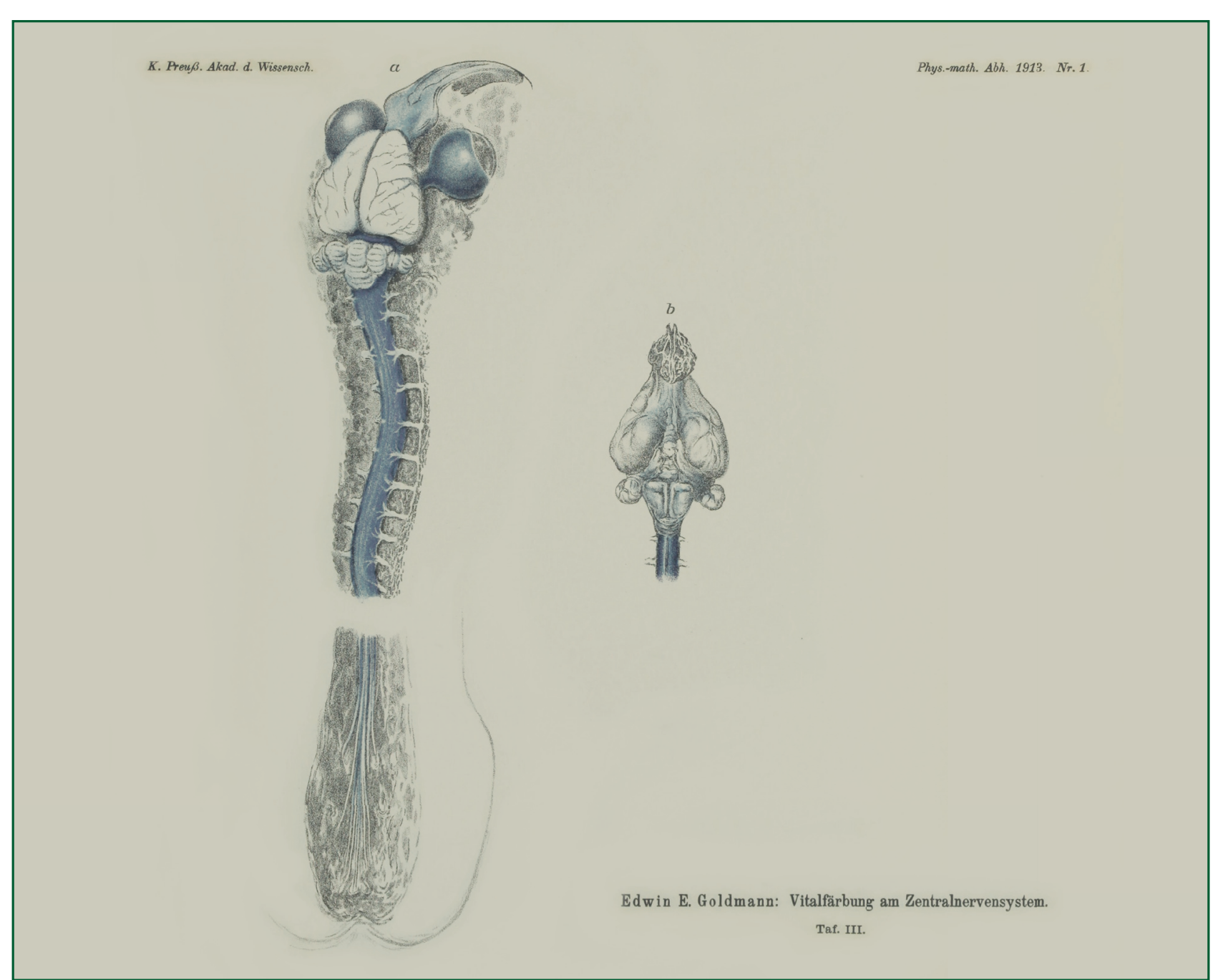

Figuur 1 Boven- en onderaanzicht (respectievelijk a en b) van de hersenen en ruggenmerg van het konijn dat lumbaal is ingespoten met een halve milliliter $0.5 \%$ tripaanblauwoplossing. Het ruggenmerg en de hersenstam kleuren blauw, net als de bulbus olfactorius, de nervus opticus en het bindweefsel van de ogen, terwijl de grote en kleine hersenen geen blauwkleuring vertonen. Uit: Vital-färbung am Zentralnerven-system. Beitrag zur Physio- Pathologie des plexus chorioideus und der Hirnhäute. E.E. Goldmann, Berlijn, 1913. 